\title{
The Rights to Belief Education in the Higher Curriculum in Indonesia
}

\author{
Tuti Widyaningrum \\ \{tuti.widyaningrum@gmail.com\} \\ Universitas 17 Agustus 1945 Jakarta, Indonesia
}

\begin{abstract}
The adherents of belief still facing discriminations about the implementation of belief education in the higher curriculum because the Higher Education Law still only recognizes religious education as a compulsory curriculum. This has resulted in discrimination for students who are adherents of belief so that they do not obtain religious education as they should be as a form of freedom of belief in God Almighty which is protected by the constitution as that of the adherents of religion. This research using juridical normative method by doing an abstraction of the process of deduction from the prevailing positive legal norms about constitutions and human rights law. This research aims to breaking the chain of discriminations against believers with giving new perspectives for recognizing belief education into compulsory curriculum in higher education law in Indonesia. Therefore, it is fundamental to immediately recognize education of belief in God Almighty and include it in the higher education curriculum as a form of respect for human rights and citizen rights of the adherents of belief in Indonesia.
\end{abstract}

Keywords: Citizen Rights, Believers, Belief Educations, Curriculum

\section{Introduction}

In a constitutional state, one of the important elements is the equal position of citizens before the law and government which is guaranteed in Article 27 Paragraph (1) of the 1945 Constitution. When a person becomes a citizen, he/she will immediately become an active subject with no discrimination in enjoying their rights and the implementation of their obligations as citizens. The Indonesian state, which was founded with a noble desire to have a free national life, has placed the God The Only One in a special position. Article 29 Paragraph (1) of the 1945 Constitution stipulates that the Indonesian state is based on the one and only God, showing the religiosity side of the Indonesian nation that will never enjoy independence other than because of the grace of Allah The Almighty. Then to ensure that independence is manifested in the spiritual sphere of the Indonesian nation, Article 29 Paragraph (2) of the 1945 Constitution has been stipulated as a guarantee of freedom of religion in Indonesia. Furthermore, Article 29 Paragraph (2) becomes the basis for thinking that the implementation of a rule of law based on Pancasila is based on religious values (religious nation-state) [1]. This rationale was taken by religious groups to legitimize that all state administration, especially those related to citizens' rights and human rights, must depart from religious values. Article 29 Paragraph (2) of the 1945 Constitution becomes the basis for the implementation of citizens rights such as the rights to marriage, employment, citizenship status, social security, education, health, and other constitutional rights stated in the 1945 Constitution. 
These constitutional rights are the embodiment of respect for human rights protected by the state. The supreme treaty in the state of law places the rights of citizens, which are derived from human rights, as the responsibility of the state to respect, protect and, fulfill. In John Locke's view, the government's duty is to protect the people and or the rights of the people because the state is held to do that [2]. The rights of citizens include the right to education as listed in Article 28C paragraph (1) and Article 28E Paragraph (1) of the 1945 Constitution, stating that every citizen has the right to obtain education and choose education.

The relationship between the recognition of religious freedom in Article 29 Paragraph (2) of the 1945 Constitution and the right to education is manifested in the recognition of religious education in the curriculum. In relation to the field of education, the right to education specifically discussed in this study is related to the religious education curriculum in schools as part of an effort to educate children according to their religious beliefs. For adherents of official religions (Islam, Christianity, Catholicism, Hinduism, Buddhism, and Confucianism) the right to religious education for the children is not a problem because the constitution has been derived into implementing regulations in the National Education System Law and the Higher Education Law for both primary and secondary education as well as higher education which regulates the existence of religious education as a compulsory curriculum.

However, the conditions are different regarding the right to belief education in the curriculum in schools and higher education for the adherents of belief. In the development of state life, the right to freedom of religion/belief of ancestors has not been fully recognized and guaranteed in terms of believing, worshiping, and practicing the teachings of their beliefs as enjoyed by the 6 major religions that are "officially" recognized by the Government. Due to the different perspectives in understanding the notion of religion and belief, citizens who belong into the category of adherents of belief not benefiting from the right to freedom of religion and belief.

So far, religious education in schools is not only a matter for the Ministry of Education and Culture, but also a concern for the Ministry of Religion through the Regulation of the Minister of Religion No. 16 of 2010 regarding the management of religious education in schools. Article 7 paragraph (1) states that the Religious Education Curriculum is compiled, developed, and implemented by education units in accordance with the National Education Standards. The specialization of religious education which only accommodates religion without including belief is then corrected by the Minister of Education and Culture Regulation No. 27 of 2016 regarding Education Services of Belief in God Almighty in Education Units, which states that students fulfill religious education requirements through belief education by following the provisions of the laws and regulations on the curriculum.

The Minister of Education and Culture Regulation No. 27 of 2016 regarding Education Services of Belief in God in the Education Units has become the basis for implementing belief education services for children of adherents of belief in education units. However, in this regulation, belief education must be based on a belief organization, namely MLKI, which implies the will of the State to fulfill the rights of the community. In several regions in Indonesia, it has accommodated belief education for the believers in education units from elementary to secondary levels.

Meanwhile, belief education services in higher education has no regulations. Law No. 12 of 2012 concerning Higher Education in Article 35 Paragraph (3) states that the Higher Education Curriculum must contain religion as a compulsory subject besides Pancasila, Citizenship, and Indonesian Language. Even though the Constitutional Court Decision No. 97/PUU-XIV/2016 has placed belief in God as equal and parallel to "religion". Nevertheless, the equal position of religion and belief has not immediately changed all aspects of the believers" 
life, including the right to belief education in the higher education curriculum in Indonesia. This shows that the benefits of having equal status of citizens through recognition of basic rights in the field of education have not reached the believers even though education is the basis to develop whole human beings. It seems that the recognition of the right to freedom of belief in the field of belief education in higher education is still discriminatory and does not guarantee equal treatment for citizens. This study looks into the recognition of the rights to belief education in the higher education curriculum in Indonesia. It is hoped that this research can become the basis for legislators to be more accommodating to the right of belief education so that they can fulfill the ideals of the state welfare in Indonesia.

\section{Research Method}

This study employs juridical normative method or normative legal research approach by doing an abstraction of the process of deduction from the prevailing positive legal norms, namely examining the law as a positive norm using deductive thinking and based on coherent truth, where the truth in this study has been declared credible without having to go through a testing or verification. This study used secondary data which were analyzed with statue approach and conceptual approach to find the answers for the research questions.This study looks at the gap in the provisions of the rights of practicing citizens in developing themselves to choose education and teaching according to their beliefs. The basic norms in the constitution which were then elaborated on the provisions of the Law on Human Rights and confirmed by the Constitutional Court Decision No. 97/PUU-XIV/2019 were used as a touchstone against the National Education System Law which only accommodates religious education as a compulsory curriculum. The author provides solutions to problems with a statutory approach and a conceptual approach accompanied by basic arguments from theories about the welfare state law, citizens' rights and human rights.

\section{Result and Discussion}

In principle, the fulfillment of citizens' rights in the field of civil, politics, social, culture, and economy in Indonesia begins with the recognition of religious freedom as stipulated in Article 29 Paragraph (2) of the 1945 Constitution. This is because, so far, religion as the main identity of the citizens becomes an administration requirements in accessing services for citizens' rights and guaranteeing the fulfillment of human rights. There is no one area of life in Indonesia that does not include the category of religion as a prerequisite, such as admission to school, wedding, working, and matters of funeral and inheritance. These rights depend on to the religion adhered to by citizens with protection of the existence, guidance, and facilitation of the state by the Ministry of Religion. From the Ministry of Religion, the politics of religion spread to various fields and influence the policies of related ministries in the implementation of human rights and citizens' rights.

One of the characteristics of an Indonesian constitutional state based on Pancasila, apart from respecting human rights, is equality before the law and the government. The equal position of citizens guaranteed in Article 27 of the 1945 Constitution should be realized in all areas of life including the right to freedom of religion. The implementation of the right to freedom of religion which benefits the fulfillment of human rights and the rights of other citizens should be 
enjoyed by all Indonesian citizens. In the field of education, adherents of religion also benefit from Article 29 Paragraph (2) of the 1945 Constitution. Both formal and non-formal education related to religious education and teaching for children of religious adherents can be enjoyed. The freedom to teach religion is accommodated by the inclusion of religious education in the curriculum from primary education to higher education.

However, this becomes different when discussing the adherents of belief who do not embrace a religion but believes in God Almighty. The latest data on the belief organizations registered at the Ministry of Education and Culture in 2017 amounted to 188 organizations spread across Indonesia with a total of $11,288,957$ people [3]. It is possible that the number will increase as 14 provinces will be included in the data. In addition to those listed, there are still many beliefs that do not belong to organizations and/or having a very small scope.

The history of clashes between religious groups and belief groups in Indonesia began in the 1950s. At that time, belief had a significant development, with 73 local religious groups. Concerned about the development of local religions, the Ministry of Religion issued a definition of religion which stipulated that a religion must have a prophet, holy book, and international recognition. This definition was rejected by Balinese Hindus and followers of the faith. The purpose of this definition was to suppress the growth of local beliefs that are considered dangerous to Islam. The discourse raised was that believers of faith are the main supporters of the Indonesian Communist Party (Partai Komunis Indonesia/PKI) hence their teachings are contrary to Islam [4, p. 69].

Tensions and conflicts between adherents of beliefs and religions culminated in the $\mathrm{G} 30$ September incident which eventually led President Soekarno to issue Law No. 1 PNPS/1965 concerning the Prevention of Abuse and/or Defamation which confirmed the official religions of the state and punished the beliefs as defamers of the six religions [4, p. 71]. Since then, the beliefs and the believers have been completely eliminated from religious life in Indonesia. The official definition of the state became the basis for the belief to be excluded from the Ministry of Religion in 1978. Subsequently, the management of beliefs was given to the Sub-Directorate of Belief in God at the Ministry of Education and Culture (Kementrian Pendidikan dan Kebudayaan/Kemdikbud).

It was a normative mistake when the beliefs were taken care of by the Ministry of Education and Culture because it contains cultural values and characteristics that lead to externum forums. However, the government allowed the differentiation of treatment in the internum forum which should have been the base of belief manifestation and derived the citizen rights of the believers. It seems that since the management was handed over to the Ministry of Education and Culture, the regulation of the citizen rights of the believers is limited to the technical administration of educational services. Even though there is a Joint Regulation of the Minister of Education and Culture with the Minister of Home Affairs No. 43 and 41 of 2009 concerning Guidelines for Service to Believers in God, it is unable to answer the need for legal regulation and protection of the believers in civil, political, and socio-cultural rights.

\subsection{The Weakness Curriculum against Believers}

Education for the believers has been regulated under the Regulation of the Minister of Education and Culture No. 27 of 2016 concerning the Educational Services of Belief in God in the Education Unit. It is explicitly stipulated in Article 2 to Article 4 of the Regulation No. 27 of 2016 regarding the technical implementation of the belief education for students in schools. These articles state about the existence of belief educators who must adjust the belief education curriculum compiled by the Belief Council. Furthermore, in the provision of Belief Education 
as referred to in Article 2, the Central Government, Regional Government, and educational units can cooperate with the Organization of Belief in God which has been registered in accordance with the statutory regulations.

In the Regulation of the Minister of Education and Culture No. 27 of 2016, although there are provisions on education for believers, none provide a guarantee of full freedom that is not related to the organization of believers. Education for the children of believers is still strongly dependent on the believer organization. Meanwhile, the organization of belief in God at the central level, which is said to embrace the believers, cannot be seen as a representation of the various kinds of existing beliefs. Seemingly, there is still a covert coercion behind the absence of belief teachers, but at the meantime, students must still have a score for the subject of religion in their report cards. Thus, they cannot help but take religion subject from one of the official religions.

Although the laws and regulations issued by the Ministry of Education and Culture are a step forward in the field of education, they are only limited to a response to the responsibility for managing the believers under the ministry. Apart from the many weaknesses in educational services for believers, a legal gap exists in the basis of the Regulation. Law No. 20 of 2003 concerning the National Education System has not yet regulated the implementation of belief education for the adherents of belief because it only accommodates the interests of the religions in the curriculum. Similarly, this also happens to the management of the belief education curriculum in the higher education setting.

One important variable that determines the efforts to improve the quality of education is the quality of the curriculum. This means that the formulation of a quality curriculum has a significant effect on the quality of education. The demand for quality education is a challenge in formulating the quality of the curriculum. Education and curriculum are interrelated; analogous to the human body, the curriculum is the "heart" of education [5, p. 19]. In regulating higher education in Indonesia, the curriculum plays an important role in the overall higher education system. The curriculum has a strategic and central position in the delivery of education at all levels and types. The curriculum is a reference in organizing and directing all forms of educational activities to achieve educational goals. The curriculum is an educational plan, providing guidelines on the type, scope, and order of content, as well as the educational process $[6, \mathrm{p} .4]$.

In short, the journey of changing the Indonesian higher education curriculum began in 1994 through the Decree of the Minister of Education and Culture of the Republic of Indonesia No. 056/U/1994 concerning Guidelines for Higher Education Curriculum Development and Assessment of Student Learning Outcomes, in which the curriculum prioritizes the achievement of mastery of science and technology, therefore called the Content-based Curriculum. In this curriculum model, national compulsory courses are stipulated in existing study programs. Then in 2000, with the UNESCO mandate through the concept of four pillars of education, namely learning to know, learning to do, learning to be, and learning to live together, Indonesia reconstructed its curriculum concept from the Content-based Curriculum to a CompetencyBased Curriculum. The 2000 and 2002 era curriculum prioritized the achievement of competence, as a an effort to bring education closer to the labor market and industrial conditions. The Competency-based Curriculum consists of a core and institutional curriculum. In implementing the Competency-based Curriculum, the main competencies are determined by mutual agreement between universities, the professional community, and graduate users. Other supporting competencies are determined by the university itself. Encouraged by the global development which currently demands recognition of internationally equated learning outcomes and the development of the IQF, the 2012 curriculum has shifted slightly by providing an equal 
measure of learning outcomes. This curriculum is still based on achieving equalized abilities to maintain the quality of graduates. This curriculum is known as the Higher Education Curriculum [7].

\subsection{Time for Recognizing Belief Education in Higher Curriculum}

From the beginning of the higher education curriculum to the latest Law No. 12 of 2012 on Higher Education, they still only accommodate religion as a compulsory curriculum content. Based on the Law No. 12 of 2012 concerning Higher Education, it is stated that curriculum development is the right of universities; however, it is subsequently stated that it must refer to the national standards (Article 35 paragraph (1) of Law No. 12 of 2012). The National Higher Education Standards in the Regulation of the Minister of Education and Culture No. 3 of 2020 regarding the National Higher Education Standards, does not specifically regulate the curriculum. The explanation of the curriculum appears to be limited to that the national education standards are used as a reference in compiling, implementing, and evaluating the curriculum. As for the mandatory higher education curriculum, it still refers to the provisions of Article 35 paragraph (3) of Law No. 12 of 2012 concerning Higher Education, in which religion is a compulsory curriculum other than Pancasila, Citizenship, and Indonesian Language.

Thus, it can be concluded that the provisions regarding religious education in the scope of the higher education curriculum have not recognized the rights of believers to obtain and or develop belief education for students. This definitely hampers the fulfillment of the recognition and protection of citizen rights of the adherents of beliefs in the higher education setting. In addition, not recognizing belief education in the curriculum is evidence of neglect of citizen rights of the adherents of beliefs so as to perpetuate discrimination on the basis of different beliefs.

This discrimination results in the neglect and a reduction in the benefits of the State of law and welfare for every citizen. This is further rooted in the lack of a basis for regulating the right to freedom of belief. In principle, there is a legal gap in the regulation of the rights of the believers because Article 28E Paragraph (2) of the 1945 Constitution, which states that everyone has the right to freedom to have a belief, and to express thoughts and attitudes according to their conscience, cannot be elaborated in the regulation of the rights of the believers. Article $28 \mathrm{E}$ paragraph (2) of the 1945 Constitution is a recognition of the human rights of the believers which is internal and related to the right to believe in God. This article explains human rights and citizen rights of the believers in relation to their belief in God but it is not an implementable article so that the right to freedom of religion can be guaranteed by the state and implemented based on the provisions of the law.

Therefore, the Constitutional Court Decision No. 97/PUU-XIV/2016 will not automatically bring about significant changes if it is not followed by changes in laws and regulations that guarantee the fulfillment of the rights of believers in the higher education setting. It is necessary to amend Law No. 12 of 2012 concerning Higher Education which recognizes beliefs equal to religion so that it is included in the compulsory higher education curriculum. This legal gap needs to be filled so that students who are believers can also obtain an education for the belief in God in the higher education curriculum in Indonesia. Amendments to the National Education System Law and the Higher Education Law are urgently required to ensure the implementation of the believers' rights in terms of belief in God. With the change in the main regulation, it is hoped that the laws and regulations under it through the Ministry of Education and Culture regulations can be in harmony and meet the goals of higher education and fulfill the objectives of the state of law and welfare in educating the nation. 


\section{Conclusion}

Higher education is a strategic level of education for improving the quality of the nation's life. Therefore, careful consideration is needed in compiling a higher education curriculum to accommodate the need for democratic learning to educate the nation. The a legal gap in the implementation of the religious education curriculum for believers of faith is an urgent matter to be resolved immediately. The recognition of the equality of religion and to belief in God based on the Constitutional Court Decision No. 97/PUU-XIV/2016 should be followed by forming laws and regulations that accommodate the rights of believers to be recognized in the compulsory higher education curriculum. It is time for changes to the Law on Higher Education to include belief education in the compulsory curriculum as a reference for curriculum formulation in the higher education setting. By including belief education in the compulsory curriculum, it is hoped to break the chain of discrimination against the recognition of the rights of believers in education, especially in the scope of higher education. In addition, the objectives of a state of law and welfare that are oriented towards serving the rights of citizens based on human rights will be optimally fulfilled.

\section{References}

[1] Mahfud MD, dalam Konfrensi dan Dialog Nasional Negara hukum, dalam Prosiding Konferensi dan Dialog Negara Hukum dengan tema: Negara Hukum Indonesia Kemana Akan Melangkah, Jakarta 9-10 Oktober 2012

[2] H. P. Sibuea, Ilmu Negara. Jakarta: Erlangga, 2014.

[3] Direktorat Kepercayaan dan Tradisi Kementerian Pendidikan dan Kebudayaan RI, "Data Kasubdit Kepercayaan Terhadap Tuhan YME," 2017.

[4] Sudarto, Religionisasi Indonesia Sejarah Perjumpaan Agama Lokal dan Agama Pendatang. Jakarta: Gramedia Pustaka Utama, 2016.

[5] Kaimudin, "Pengembangan Kurikulum Pendidikan Tinggi," J. Al Ta'bid, vol. 8, no. 1, 2015.

[6] N. S. Sukmadinata, Pengembangan Kurikulum Teori dan Praktek. Bandung: Remaja Rosdakarya, 2013.

[7] Tim K-DIKTI, Buku Kurikulum Pendidikan Tinggi Direktorat Pembelajaran dan Kemahasiswaan. Jakarta: Direktorat Jenderal Pendidikan Tinggi Kementerian Pendidikan dan Kebudayaan, 2014. 